\title{
STUDY OF MECHANICAL PROPERTIES OF OPEN CELL AL6061 ALLOY FOAM
}

\author{
RAJA YATEESH YADAV ${ }^{1} \&$ S PRAKASH $^{2}$ \\ ${ }^{1}$ Shri Madhwa Vadiraja Institute of Technology \& Management, Bantakal, Udupi, India \\ ${ }^{2}$ University B D T College of Engineering, Davangere, India
}

\begin{abstract}
The mechanical behavior of 20 ppi open cells Al6061 alloy foam is studied under uniaxial tensile, compression and bending loads. In addition to the common stress-strain measurements, peak load, ultimate stress, displacement at peak load, break load, displacement at break load, breaking stress and Percentage reduction in the cross-sectional area for two specimens were determined. The results show that even though aluminium foams were having good thermal and damping properties, they are having poor mechanical properties hence they are not suitable load bearing structures.

KEYWORDS: uniaxial tensile, break load \& load bearing structures
\end{abstract}

Received: Aug 22, 2017; Accepted: Sep 20, 2017; Published: Oct 14, 2017; Paper Id.: IJMPERDDEC20171

\section{INTRODUCTION}

The recent development of a number of cost-effective processes for making metallic foams has increased their potential for application in sandwich panels for lightweight structural components, in energy absorption systems for protection from impacts, in heat sinks for electronic devices and acoustic insulation. [1] In the last few year structural efficiency, cost requirements and improvements in manufacturing processes have created renewed interest in metallic foams. For a successful design with this new class of materials, their mechanical properties have to be known. Most work has been performed on their compressive properties and energy-absorbing behaviour; see for example [2-5]. But for the design of load bearing structural elements such as sandwich panels, other mechanical properties (tension behaviour, fracture toughness, etc.) are needed as well. The aim of this investigation was to provide information about the tensile performance and deformation behaviour of aluminium foams.

In compression, aluminium foams show different regimes of deformation. The most important one is the plateau regime, where the stress remains nearly constant with increasing deformation. This plateau stress is caused by the initiation and propagation of deformation bands through the foam structure [6]. In these bands the deformation predominantly takes place by plastic buckling of the cell edges and cell walls. The plastic Poisson's ratio in compression at larger strains is about zero. In tension, however, it is expected that buckling plays a minor role in the deformation mechanisms. Therefore a different deformation behaviour is anticipated.

Only a few investigations (e.g., [7, 8]) exist that are concerned with this topic. In this paper, the mechanical behaviour of 20 ppi open cells Al6061 alloy foam is studied under uniaxial tensile loading. 


\section{MATERIALS AND METHODS}

\section{Physical and Chemical properties of Al6061 alloy}

The selection of the material for foam fabrication is generally based on the end application. In the present research, Aluminum 6061 alloy (Al 6061 alloy) is chosen for the foam fabrication, as it exhibits good structural, chemical, thermal, electrical, heat transfer properties and weldability. Table 1.1 shows the composition of Al 6061 alloy.

Table 1: Chemical Composition of Al 6061 Alloy by Weight Percentage

\begin{tabular}{|l|l|}
\hline $\mathrm{Mg}$ (Magnesium) & $0.920 \%$ \\
\hline $\mathrm{Si}$ (Silicon) & $0.750 \%$ \\
\hline $\mathrm{Fe}$ (Ferrous) & $0.280 \%$ \\
\hline $\mathrm{Cu}$ (Copper) & $0.220 \%$ \\
\hline $\mathrm{Ti}$ (Titanium) & $0.100 \%$ \\
\hline $\mathrm{Cr}$ (Chromium) & $0.070 \%$ \\
\hline $\mathrm{Zn}$ (Zinc) & $0.060 \%$ \\
\hline $\mathrm{Mn}$ (Manganese) & $0.040 \%$ \\
\hline $\mathrm{Be}$ (Beryllium) & $0.003 \%$ \\
\hline $\mathrm{V}$ (Vanadium) & $0.010 \%$ \\
\hline $\mathrm{Al}$ (Aluminum) & Balance \\
\hline
\end{tabular}

Table 2: Physical, Thermal, Electrical Properties of Al 6061 Alloy

\begin{tabular}{|l|c|}
\hline Density, $\mathrm{kg} / \mathrm{m}^{3}$ & 2700 \\
\hline Melting point, ${ }^{\circ} \mathrm{C}$ & 580 \\
\hline Modulus of elasticity, GPa & $70-80$ \\
\hline Co-Efficient of Thermal Expansion $\left(20-100^{\circ} \mathrm{C}\right) \mathrm{m} / \mathrm{m}^{\circ} \mathrm{C}$ & $23.5 \times 10^{-6}$ \\
\hline Thermal Conductivity, $\mathrm{W} / \mathrm{m}^{\circ} \mathrm{C}$ & 173 \\
\hline Electrical Resistivity $\Omega \mathrm{cm}$ & $3.7-4.0 \times 10^{-6}$ \\
\hline Poison's ratio & 0.33 \\
\hline
\end{tabular}

Closed cell metal foams provide good mechanical properties but do not allow access to their internal surface. Therefore, they are mostly used in structural and load bearing applications. Open cell metal foams are more suitable heat transfer applications, as they provide more surface area for the heat transfer. The present research is more concentrated on the study of heat transfer applications of metal foams, an open cell metal foam is fabricated using Al6061 alloy.

\section{EXPERIMENTAL PROCEDURE}

\section{Specimen Preparation}

The specimens were prepared by machining from commercially available 20 ppi A16061 foam. Totally five specimens of different dimensions with rectangular sections are prepared. Two of them were used for tensile test, two are used for compression test and the rest one being used for bending test.

\section{Tensile Test}

Tensile test is a fundamental materials science test in which a sample is subjected to a controlled tension until failure. The results from the test are commonly used to select a material for an application, for quality control, and to predict how a material will react under loading condition. Properties that are directly measured through tensile test are ultimate tensile strength, maximum elongation and reduction in area. Uniaxial tensile testing is the most commonly used for obtaining the mechanical characteristics of isotropic materials. The testing process involves placing the test specimen on the Universal Testing Machine (UTM) and applying the uniaxial tensile force until the specimen breaks. 
An open cell $\mathrm{Al}$ foam specimen of 20 ppi made from Al6061 alloy is cut into a required dimension using a cutter wheel and the edges are finished for mechanical testing. Two specimens are tested for the study of tensile properties.

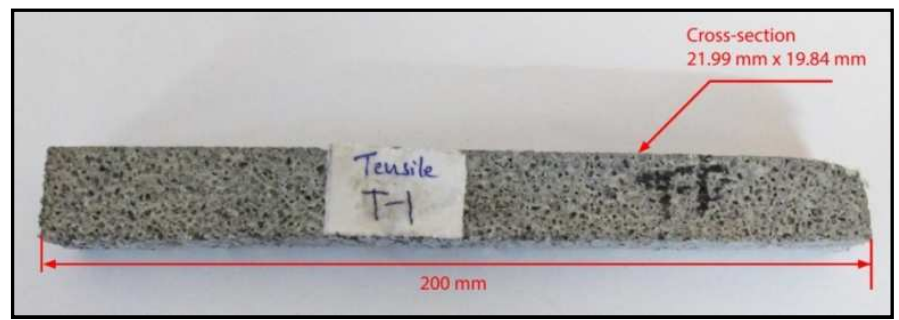

Figure 1: Tensile Test Specimen-1

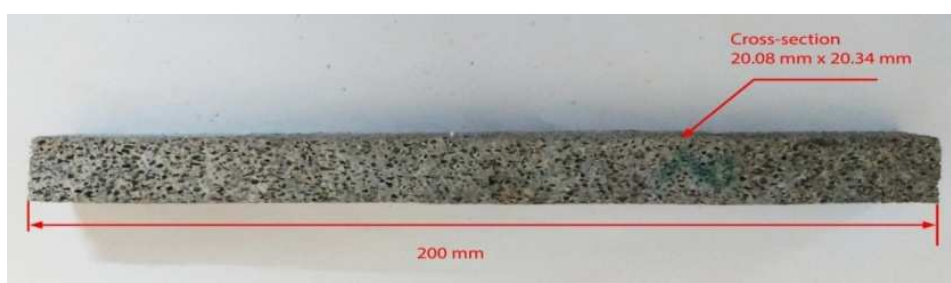

Figure 2: Tensile Test Specimen-2

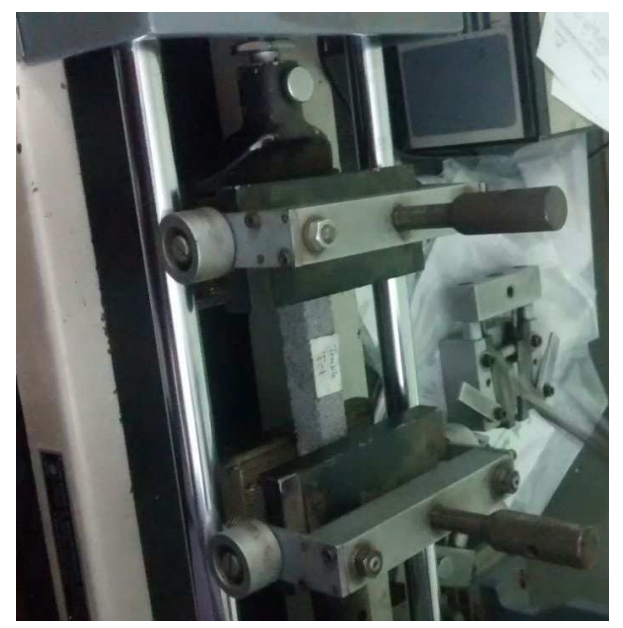

Figure 3: Tensile Test Specimen-1 under Loading in the UTM Set Up

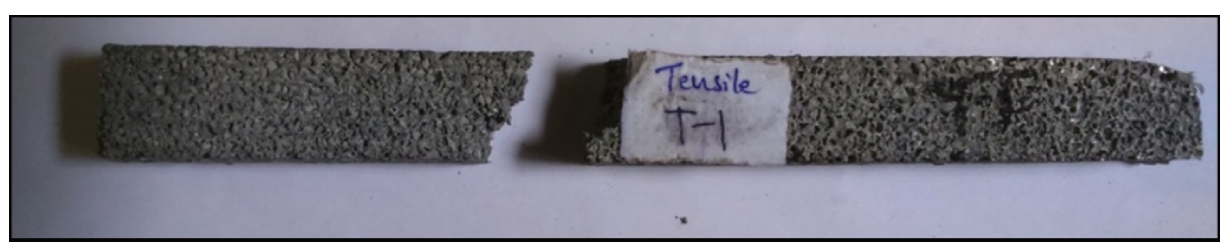

Figure 4: Tensile Test Specimen-1 after the Test

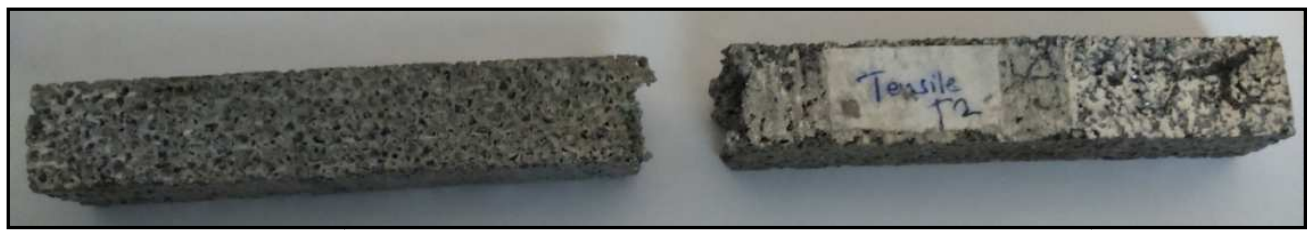

Figure 5: Tensile Test Specimen-2 after the Test 


\section{Compression Test}

Compression test is to determine the behavior or response of a material while it experiences a compressive load. In general a compression test for a material involves at least two opposing forces directed towards each other applied to the opposite face of the test sample so that the sample is compressed. Compression tests are run in much the same manner as the tension test on the specimen having an initial rectangular cross-sectional area. Testing is carried out on Universal Testing Machine. For each load interval, respective change in length is measured and the same is recorded until breaking takes place.

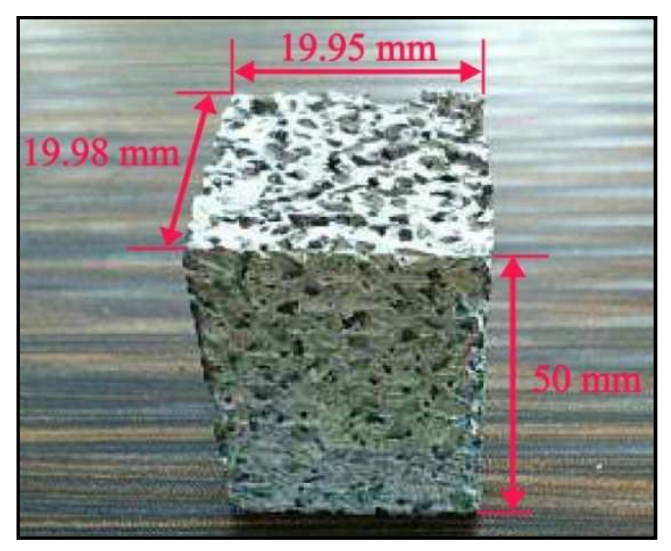

Figure 6: Compression Test Specimen-1

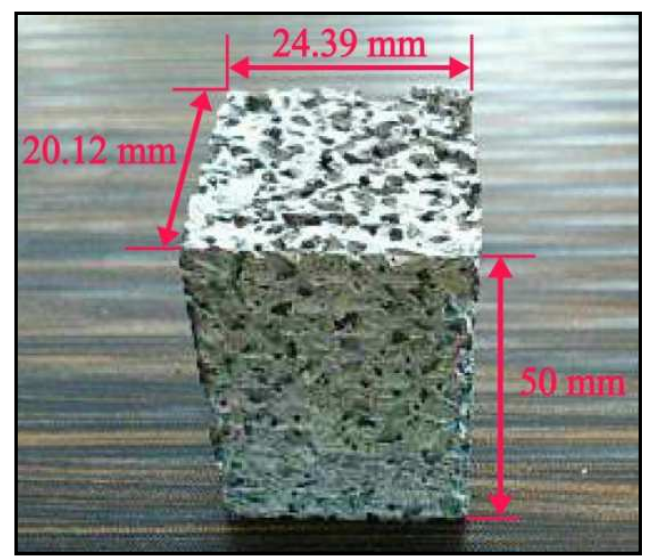

Figure 7: Compression Test Specimen-2

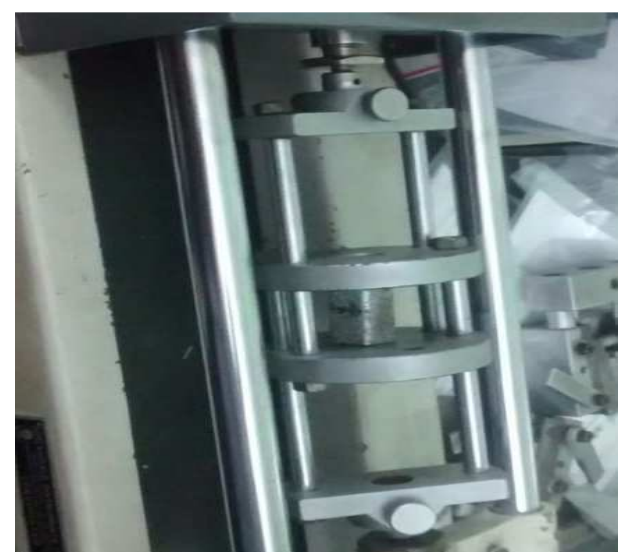

Figure 8: Compression Test Specimen under Loading in UTM Set Up 

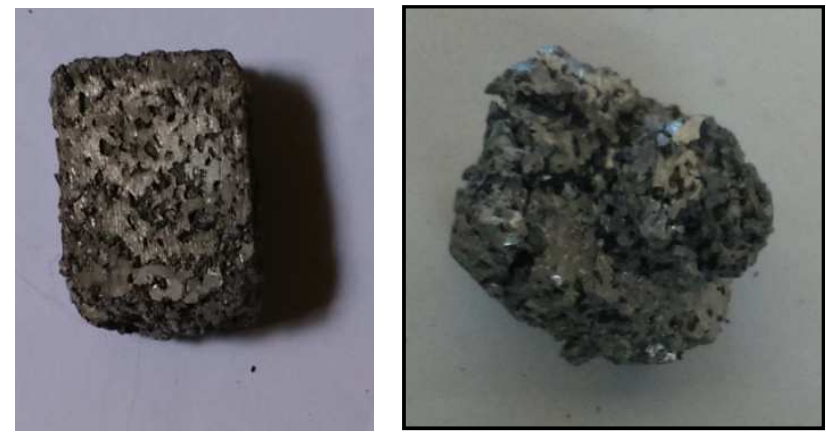

Figure 9: Compression Test Specimens after the Test

\section{Bending Test}

The bend test is essentially measuring the ductility of a specimen. Ductility defines how easily a specimen can bend without breaking. The higher the ductility of a metal, the more it can bend without breaking or becoming deformed from its original shape.

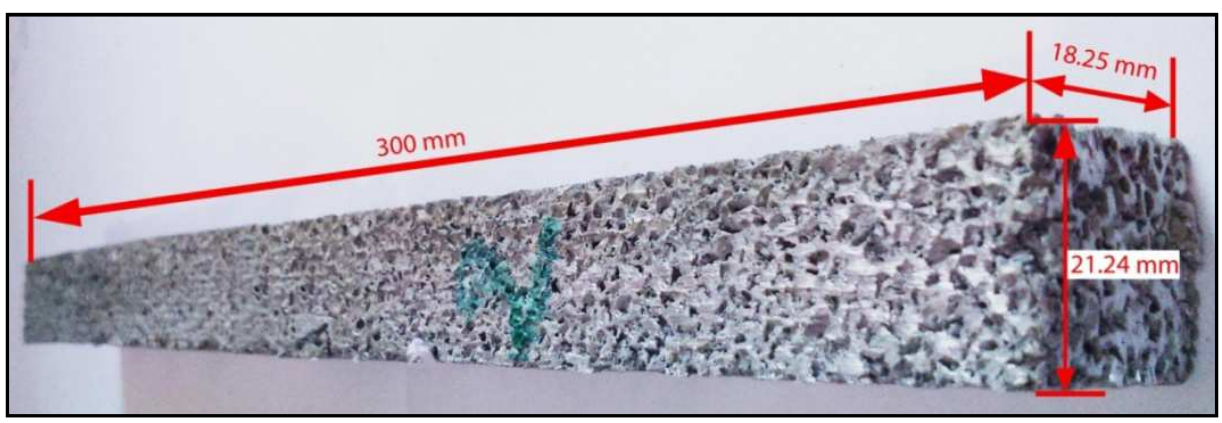

Figure 10: Bending Test Specimen-1

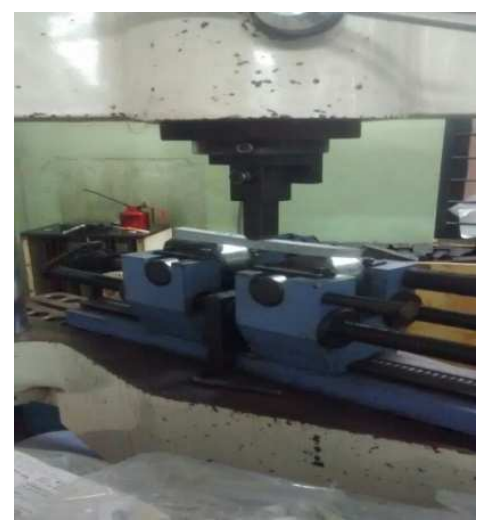

Figure 11: Bending Test Specimen under Loading in UTM Set Up

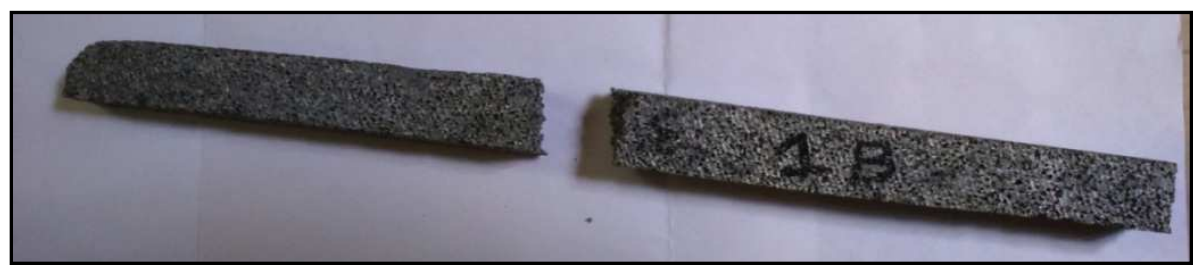

Figure 12: Bending Test Specimens after the Test 


\section{RESULTS AND DISCUSSIONS}

\section{Tensile test}

Figure-13 and Figure-14 shows the Load vs Displacement curve for tensile test specimen-1 and specimen-2 respectively. The tensile test results of the specimen-1 are as follows.

Peak load $=1726 \mathrm{~N}$

Ultimate stress $=($ Peak load $/$ Initial cross-sectional area $)=3.95 \mathrm{~N} / \mathrm{mm}^{2}$

Displacement at peak load $=1.655 \mathrm{~mm}$

Break load $=88.26 \mathrm{~N}$

Displacement at break load $=2.97 \mathrm{~mm}$

Breaking stress $=($ Break load $/$ Initial cross-sectional area $)=0.2023 \mathrm{~N} / \mathrm{mm}^{2}$

Final cross-sectional area $=411.81 \mathrm{~mm}^{2}$

Percentage reduction in the cross-sectional area $=5.60 \%$

The tensile test results of the specimen-2 are as follows.

Peak load $=3050 \mathrm{~N}$

Ultimate stress $=($ Peak load/Initial cross-sectional area $)=3.46 \mathrm{~N} / \mathrm{mm}^{2}$

Displacement at peak load $=2.138 \mathrm{~mm}$

Break load $=98.07 \mathrm{~N}$

Displacement at break load $=4.23 \mathrm{~mm}$

Breaking stress $=($ Break load $/$ Initial cross-sectional area $)=0.2401 \mathrm{~N} / \mathrm{mm}^{2}$

Final cross-sectional area $=376.53 \mathrm{~mm}^{2}$

Percentage reduction in the cross-sectional area $=7.80 \%$

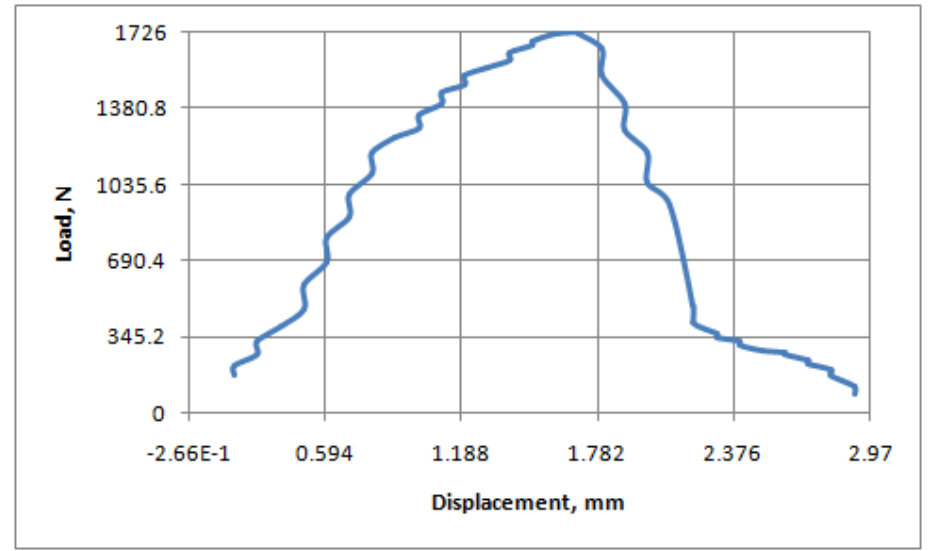

Figure 13: Load vs. Displacement Curve for Tensile Test Specimen-1 


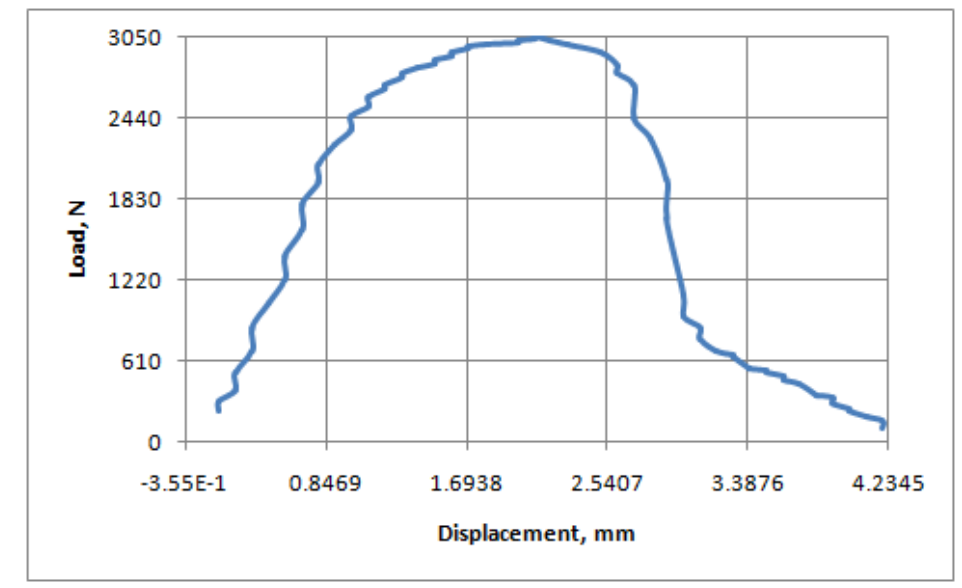

Figure 14: Load vs. Displacement Curve for Tensile Test Specimen-2

From the results of tensile test, the average maximum tensile load that the Al6061 foam specimen can take is found to be $2388 \mathrm{~N}$ and the average ultimate stress is found to be $3.70 \mathrm{~N} / \mathrm{mm}^{2}$. These values are less compared to the conventional materials used for load bearing applications.

\section{Compression Test}

Figure-15 and Figure-16 shows the Load vs Displacement curve for compression test specimen-1 and specimen-2 respectively. Compression test results of the specimen-1 are as follows.

Peak load $=15691.2 \mathrm{~N}$

Compressive stress $=($ Peak load $/$ Initial cross-sectional area $)=39.36 \mathrm{~N} / \mathrm{mm}^{2}$

Displacement at peak load $=28.309 \mathrm{~mm}$

Break load $=15691.2 \mathrm{~N}$

Displacement at break load $=28.309 \mathrm{~mm}$

Compression test results of the specimen-2 are as follows.

Peak load $=13788.60 \mathrm{~N}$

Compressive stress $=($ Peak load/Initial cross-sectional area $)=28.099 \mathrm{~N} / \mathrm{mm}^{2}$

Displacement at peak load $=11.728 \mathrm{~mm}$

Break load $=13788.60 \mathrm{~N}$

Displacement at break load $=11.728 \mathrm{~mm}$ 


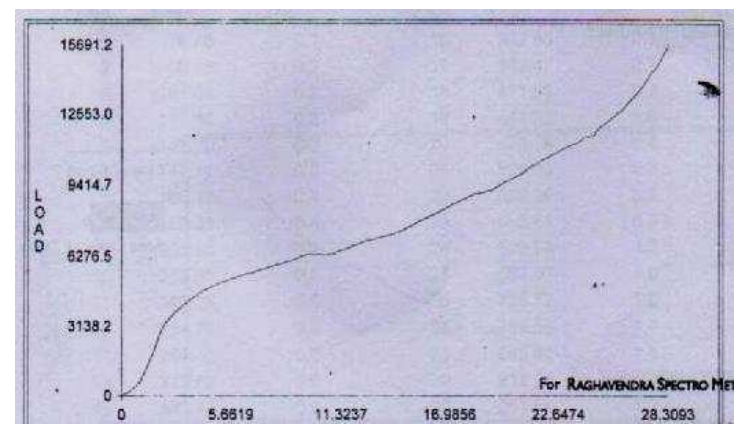

Figure 15: Load vs. Displacement Curve for Compression Test Specimen-1

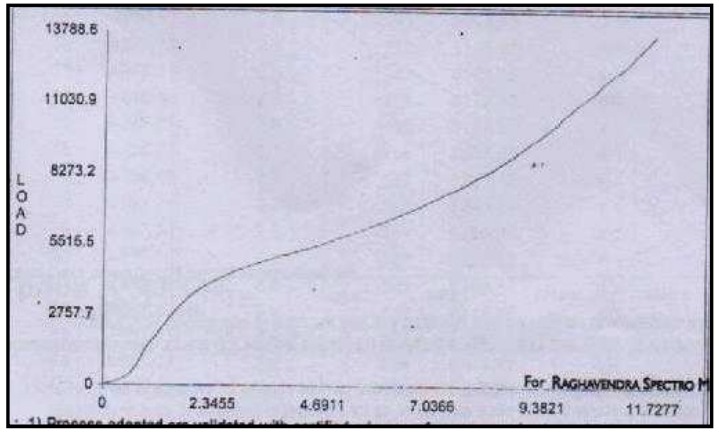

Figure 16: Load vs. Displacement Curve for Compression Test Specimen-2

From the results of compression test, the average peak load that the Al6061 foam specimen can take is found to be 14739.9 $\mathrm{N}$ and the average compression strength is found to be $33.72 \mathrm{~N} / \mathrm{mm}^{2}$. These values are less compared to the conventional materials used for load bearing applications.

\section{Bending Test}

Figure-17 shows the Load vs Displacement curve for bending test specimen. Bending test results are as follows.

Peak load: $0.340 \mathrm{kN}$

Elongation at peak: $4.95 \mathrm{~mm}$

Bending strength: $0.877 \mathrm{~N} / \mathrm{mm}^{2}$

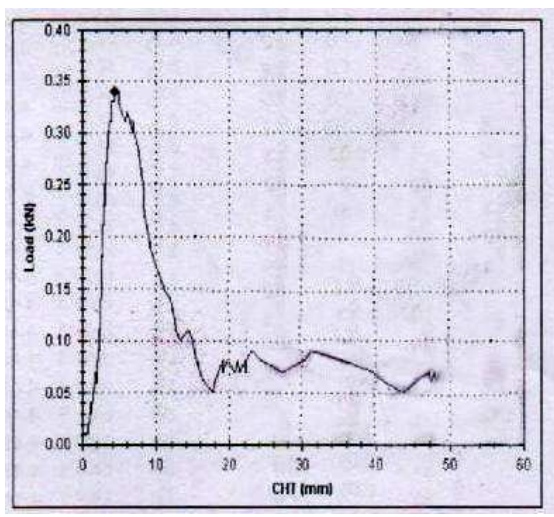

Figure 17: Load vs. Displacement Curve for Bending Test Specimen

From the results of bending test, the peak load that the Al6061 foam specimen can take is found to be $0.34 \mathrm{kN}$ and the bending strength is found to be $0.877 \mathrm{~N} / \mathrm{mm}^{2}$. These values are less compared to the conventional materials used for 
load bearing applications.

\section{CONCLUSIONS}

A 20 ppi Al6061 alloy foam specimen is tested for uniaxial tensile, compression and bending loads. Based on the results, the following conclusions can be made.

- The ultimate tensile strength of Al6061 alloy foam specimen is found to be $3.70 \mathrm{MPa}$. This value is very less compared to ultimate tensile strength of mild steel, a conventional material whose ultimate tensile strength will be around $841 \mathrm{MPa}$. Hence Al6061 alloy foam cannot used for structures required to bear tensile loads.

- The ultimate compression strength of Al6061 alloy foam specimen is found to be $33.72 \mathrm{MPa}$. Again, this value is very less compared to the ultimate compression strength of mild steel, a conventional material whose ultimate compression strength will be around $250 \mathrm{MPa}$. Hence Al6061 alloy foam cannot used for structures required to bear compression loads too. Also, the specimen tested is of open cell type, the specimen is almost squeezed at the end of the test.

- Also, porous materials cannot be used applications, where the structures are subjected to bending loads, as foam is a very brittle material.

\section{REFERENCES}

1. E. Andrews, W. Sanders, L.J. Gibson "Compressive and tensile behaviour of aluminum foams" Materials Science and Engineering A270 (1999) 113-124

2. Bart-Smith, H., Bastawros, A. -F., Mumm, D. R., Evans, A. G., Sypeck, D. J. and Wadley, H. N. G., Acta. mater., 1998, 46(10), 3583.

3. Fusheng, H., Zhengang, Z. and Junchang, G., Metall.Mater. Trans., 1998, 29A, 2497.

4. Gradinger, R. and Rammerstorfer, F. G., Acta. mater.,1999, 47(1), 143.

5. Andrews, E., Sanders, W. and Gibson, L. J., Mater. Sci. Eng., 1999, A270, 113.

6. Bastawros, A. -F., Bart-Smith, H. and Evans, A. G., J. Mech. Phys. Solids, 2000, 48, 301.

7. Sugimura, Y., Meyer, J., He, M. Y., Bart-Smith, H., Grenstedt, J. and Evans, A. G., Acta Mater, 1997, 45(12), 5245.

8. Olurin, O. B., Fleck, N. A. and Ashby, M. F., Mater. Sci. Eng., 2000, A291, 136. 
